POLSKA AKADEMIA NAUK —ZAKEAD BADANIA SSAKOW

A C C T A

Vol. V, 6 .

BIAŁOWIEŻA

10. VI. 1961

Tadeusz R OSKOSZ \& Wojciech E MPEL

\title{
The Size of the Head and the Height of Spinous Processes in the Region of the Withes of the European Bison, Bison bonasus (Linnaeus 1758)
}

\section{Wielkość glowy a wysokość wyrostków kolczystych okolicy kłębu u żubra, Bison borlasus (L i n n a u s 1758) \\ Bisoniana IV}

[With 2 tables and 5 phots.]

\section{INTRODUCTION}

The spinous processes, processus spinales of the first thoracic vertebrae of the European bison form a stroma for the withers and are distinguished by a considerable height in comparison with other Bovinae. Koch (1932) considers that the height of the spinous processes of the first thoracic vertebrae depends on the weight of the skull. P o p le w s k i (1949) tries to explain this state of things, ascribing the existence of strongly developed withers in the bison to a considerable weight of the head of this species.

When comparing the skulls and thoracic vertebrae of different Bovinae collected in the Museum of the Department of Animal Anatomy of the Central College of Agriculture in Warsaw, we came to the conclusion that the size of the head, and also its weight, is not the only factor influencing the height of the spinous processes of thoracic vertebrae. A variety of the African zebu, the Watussi cattle, characterized by their powerful processus cornus greatly influencing the weight of the head, have relatively low spinous processes of the first thoracic vertebrae

We present in this work some measurements which characterize the size of skulls and the highest spinous processes of the thoracic region of European bisons of both sexes, comparing them with the same values for a male and a female of Watussi cattle. We also endeavour to detect the cause of the special development of spinous processes in the area of the withers in the European bison. 
Disposing only of bone material we could not determine the weight of complete heads. We assume however that the size of the skull and its weight, when using the same maceration methods, can give a certain notion as to the size of the entire head and its weight.

In the case of the thoracic region of the vertebral column of the European bison, according to data from literature $-\mathrm{Koch}$ (1932), J a n i cki (1938), J us ko (1953) - the highest spinous process is that of the second thoracic vertebra; our own observations state that the highest spinous process is that of the second or, much less frequently, of the third thoracic vertebra. In our measurements we only took in consideration the height of the highest spinous process.

\section{MATERIAL AND METHOD}

Investigations were carried out on 30 skeletons of European bison of different age, 18 females and 12 males, and on 2 skeletons (a male and a female) of Watussi cattle. The age of the European bisons was determined after the „Pedigree Books of the European bison”. The approximate age of the Watussi cattle is based on data from the Zoological Garden in Warsaw.

The following measurements were carried out, in accordance with the work of Duerst (1926):

1. Length of profile, Opisthokranion - Prosthion.

2. Smallest frontal breadth, Frontostenion - Frontostenion.

3. Greatest breadth of the cranium, measured on processus cornus.

4. Circumference of the base of processus cornus.

5. Height of the largest spinous process of the thoracic region.

6. Weight of skull.

\section{ANALYSIS OF RESULTS}

Table 2 contains the measurements of skulls mentioned above which can provide a certain notion as to their size both in Watussi cattle and in the investigated European bisons. For the latter ones only extreme results for animals above 5 years of age were given. Detailed measurement data for all investigated European bisons, their names and age can be found in Table 1 .

As results from the analysis of Table 2, the skulls of Watussi cattle are similar in length to the longest skulls of investigated European bisons. The smallest frontal breadth of a Watussi male approaches the lowest values of this measurement in the European bison; it is slightly lower for the female Watussi than the smallest measurement of European bison. Measurements illustrating the size of the processus cornus of Watussi cattle are considerably superior to those of the European bison. The greatest breadth of the skull, measured on the processus cornus is about twice greater for the Watussi male, and about three times greater for 
Table 1.

Osteological measurements and weight of skulls of European bison. (Measurements in $\mathrm{mm}$, weight in $\mathrm{kg}$.).

\begin{tabular}{|c|c|c|c|c|c|c|c|c|c|c|}
\hline$\dot{0}$ & $\begin{array}{l}\dot{0} \\
\dot{a} \\
\dot{-1} \\
\dot{0}\end{array}$ & 异 & 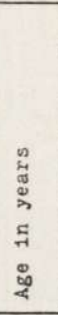 & 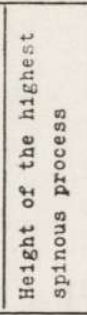 & 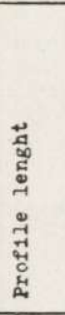 & 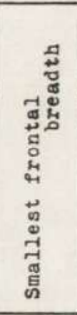 & 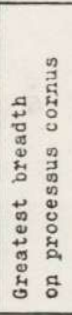 & 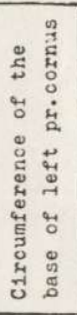 & 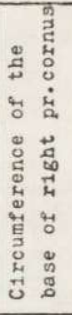 & 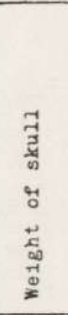 \\
\hline \multicolumn{11}{|c|}{ F e m a 1 e $s$} \\
\hline 1. & 13 & Plinka & 2 & 226 & 400 & 190 & 379 & 124 & 130 & 1.40 \\
\hline 2. & 24 & Plusia & 3 & 276 & 445 & 200 & 443 & 143 & 144 & 1.70 \\
\hline 3. & 12 & Pup1leczka & 3 & 309 & 471 & 186 & 419 & 127 & 135 & 2.10 \\
\hline 4. & 16 & Plebanka & 5 & 324 & 480 & 227 & 552 & 187 & 190 & 2.10 \\
\hline 5. & 31 & Plama & 6 & 320 & 474 & 218 & 466 & 170 & 168 & 2.30 \\
\hline 6. & 25 & Pl1sa & 7 & 314 & 485 & 213 & 489 & 167 & 168 & 2.70 \\
\hline 7. & 27 & Plewa & 7 & 310 & 473 & 201 & 449 & 149 & 148 & 2.40 \\
\hline 8. & 22 & Purchawka & 7 & 368 & 487 & 202 & - & 156 & 153 & 2.60 \\
\hline 9. & 17 & Puszcza & 9 & 349 & 489 & 204 & - & 149 & 161 & 2.90 \\
\hline 10. & 8 & Plast1k II & 11 & 349 & 479 & 206 & 498 & 179 & 183 & 2.40 \\
\hline 11. & 20 & Pura & 11 & 387 & 500 & 215 & 448 & 161 & 160 & 2.40 \\
\hline 12. & 34 & Poz1 omika & 12 & 357 & 502 & 225 & 451 & 165 & 168 & 2.40 \\
\hline 13. & 36 & Plarka & 12 & 326 & 475 & 206 & 424 & 172 & 179 & 2.00 \\
\hline 14. & 11 & Pużanka & 15 & 365 & 512 & 215 & 507 & 181 & 177 & 2.80 \\
\hline 15. & 4 & PIötze & 16 & 339 & 486 & 213 & 468 & 178 & 184 & 2.80 \\
\hline 16. & 3 & Planarie & 18 & 320 & 482 & 219 & 504 & 183 & 184 & 2.70 \\
\hline 17. & 15 & Pleinze & 18 & 314 & 486 & 207 & 469 & 180 & 180 & 2.30 \\
\hline 18. & 30 & Pllete & 18 & 355 & 482 & 201 & - & - & 187 & 2.50 \\
\hline \multicolumn{11}{|c|}{ M $\quad$ a $\quad 1 \quad$ e $s$} \\
\hline 1. & 29 & Puzan & $1^{1 / 1}$ & 222 & 387 & 200 & 450 & 142 & 141 & 1.00 \\
\hline 2. & 18 & Pustak & 4 & 361 & 517 & 249 & 650 & 205 & 205 & 1.80 \\
\hline 3. & 14 & Pleban & 5 & 373 & 523 & 244 & 615 & 208 & 209 & 4.10 \\
\hline 4. & 10 & Puszek & 5 & 385 & 526 & 256 & 631 & 196 & 200 & 4.40 \\
\hline 5. & 26 & Plotikarz & 6 & 402 & 513 & 238 & 643 & 208 & 212 & 4.80 \\
\hline 6. & 39 & Plater & 7 & 393 & 523 & 241 & 642 & 214 & 214 & 3.60 \\
\hline 7. & 35 & Poganin & 8 & 467 & 556 & 270 & - & - & 235 & 5.50 \\
\hline 8. & 32 & Pustelnik & 8 & 448 & 522 & 243 & 572 & 219 & 219 & 3.80 \\
\hline 9. & 2 & Polamantec & 9 & 467 & 525 & 241 & 638 & 212 & 210 & 5.50 \\
\hline 10. & 37 & Pluvius II & 17 & 432 & 509 & 240 & 662 & 240 & 239 & 4.50 \\
\hline 11. & 38 & Plato & 17 & 471 & 534 & 236 & 578 & 239 & 233 & 3.90 \\
\hline 12. & 5 & Pulk & 17 & 475 & 558 & 266 & 697 & 260 & 261 & 5.90 \\
\hline
\end{tabular}

1) Exactly 13 months.

the Watussi female in comparison with the European bison. Similarly, the circumference of the base of processus cornus is considerably greater in Watussi cattle. 
Table 2.

Comparison of osteological measurements of European bison and Watussi cattle.

\begin{tabular}{|l|c|c|c|c|}
\hline Measuremets in mm. & $\begin{array}{c}\text { B1sons, } \\
88^{8} \\
5-18 \text { years }\end{array}$ & $\begin{array}{c}\text { Watussi, } \\
\text { ca } 9 \text { yrs }\end{array}$ & $\begin{array}{c}\text { Bisons, } \\
\text { f9 } \\
5-18 \text { yrs }\end{array}$ & $\begin{array}{c}\text { Watuss1, } \\
\text { ca } 8 \text { yrs }\end{array}$ \\
\hline Profile length & $509-558$ & 540 & $473-512$ & 507 \\
Smallest frontal breadth & $236-270$ & 245 & $201-227$ & 179 \\
Greatest breadth on processus cornus & $572-697$ & 1230 & $424-552$ & 1300 \\
C1rcumference of the base of pr. cornus & $196-261$ & 380 & $148-190$ & 285 \\
He1ght of the highest pr. spinalis & $373-475$ & 319 & $310-387$ & 274 \\
\hline We1ght of skull in kg. & $3.60-5.90$ & 9.50 & $2.00-2.90$ & 7.10 \\
\hline
\end{tabular}

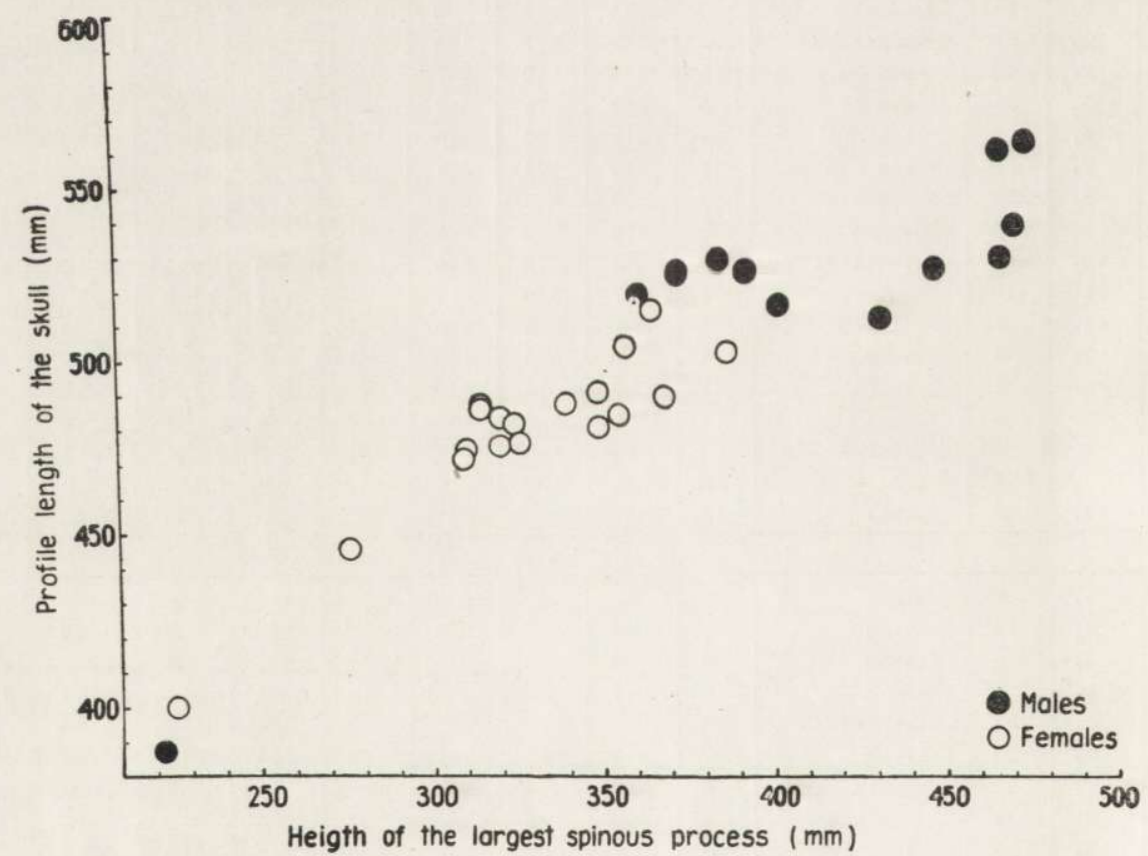

Fig. 1. Correlation between the profile length of the skull and the height of the largest spinous process in European bison.

In Table 2 weight data of the skulls are also presented. It appears clearly that the skull of the Watussi male is nearly twice as heavy as the heaviest skull of the European bison, the skull of the female being 2.5 times heavier in comparison with the heaviest skull of the European bison female. 
The table mentioned above contains for comparison, measurements of the height of the highest spinous processes of the thoracic vertebrae. It appears that this measurement in investigated specimens of Watussi cattle is much lower when compared with the European bison, even in individuals with relatively low spinous processes, both males and females.

It can be inferred from Fig. 1, that among European bisons the size of the head has a certain influence on the height of spinous processes.

\section{DISCUSSION}

The above analysis proves that the considerable height of the spinous processes of thoracic vertebrae is not induced by a specially large head of the animal. Watussi cattle have a decidedly greater head than the European bison, but their spinous processes are considerably lower in comparison (phot. 1-5, Plate VI \& VII). In the limits of one single species and in identical biomechanical conditions the size of the head influences undoubtedly the formation of spinous processes; this can be proved by observation of the European bisons (Fig. 1).

The increase of spinous processes, independently of the above, is also connected with other factors. Kry si a k (1951) in his work on the nuchal ligament of the European bison analysed static and mechanical factors of the region which is of interest for us. He proved that the nuchal ligament is not a direct factor inducing the growth of spinous processes. The funicular part of the nuchal ligament of the European bison is not attached to the apex of these processes but is disposed on the sides of the spinous comb. The summits of the spinous processes of the first thoracic vertebrae exceed the upper borders of the tapes of the nuchal ligament. The spinous processes are, as it appears, too high for the needs of the nuchal ligament. Krys i a k in the above mentioned work indicates also that the direct cause of such a strong development of these processes are the muscles of the epaxial system.

We found interesting data concerning muscles of the region of the withers in the work of Swi e żyński (1961). Muscles having insertions on the spinous processes of the withers are especially well developed in the European bison. This concerns above all the splenius, musculus splenius, bearing the head and straightening 
the neck; the musculus spinalis dorsi; the musculus spinalis cervicis and the powerful extrinsic muscle of the pectoral limb of the European bison - musculus rhomboideus.

As results from the above, the growth of spinous processes is influenced not only by the muscles that lift the head and straighten the neck but also by spinal muscles and those of the trunk and extremities. We must therefore seek more universal factors influencing the spinous processes by analysing the functions of the muscles mentioned above.

A characteristic of the European bison is a special posture of the head. The European bison, when standing at rest and even when moving, carries its head relatively low, below the line of the back. However, they feed willingly on branches of shrubs and on the bark of trees at a height (a fact interesting to note) which forces them to lift their head frequently. This necessitates clearly strongly developed muscles which lift the head.

High spinous processes, on which these muscles can obtain an insertion, magnify the angle formed by tendon and bone which causes a greater functional effect provoked by a smaller effort. As to Watussi cattle, similarly as for our domestic cattle, the line of the back passes onto the line of the neck quite straightly.

The length of the neck may also have a certain influence on the development of the epaxial muscles of the neck (K r y sia k, 1951). In the species compared by us this factor is of no importance as the length of the neck, measured on the body of the vertebrae, is similar for the European bison and the Watussi cattle.

Spinous processes connected with each other by muscles and ligaments form a construction increasing the endurance of the vertebral column. The spine itself in the European bison is strongly curved towards the dorsum, which also strengthens its endurance. The high spinous processes and the characteristic bend of the thoracic region of the vertebral column are undoubtedly in relation to the considerable weight of the body of the European bison and the strongly developed anterior part of the animal.

The powerfully developed extrinsic muscles of the pectoral limb might well be explained by the specific gait of the European bison. Before bringing its weight to bear upon its foreleg, the European bison executes as if a ,probatory weighting”, during which the entire weight of the anterior part of the animal is sustained by the limb of the opposite side. 
Finally, attention should be directed to the fact, that the European bison, in spite of the great bulk of its body, is a very active animal, and leaps over an obstacle $2 \mathrm{~m}$ high, with no preparatory running, have been noted. This great efficiency of movement of the European bison increases still more the claim upon the muscular system and also, as a result, upon the skeletal system.

\section{SUMMARY}

The authors disposed of 30 skeletons of European bison (18 females and 12 males) and of 2 skeletons of Watussi cattle (a male and a female). The animals were of a different age and came from Polish National Reservations or from the Warsaw Zoo. Skulls and spinous processes of the highest thoracic vertebrae were investigated and subsequently measured. The skulls were also weighed (Tables 1-2, Fig. 1).

Our investigations permitted to state that the very considerable height of spinous processes in the region of the withers is not caused by a specially large head in the European bison. Watussi cattle have considerably greater heads and their spinous processes are nevertheless much lower when compared with European bisons.

The authors consider that the powerful muscles of the region of the withers ( $m$. splenius, $m$. spinalis dorsi, m. spinalis cervicis, $m$. rhomboideus) are decisive factors concerning the considerable growth of spinous processes. These muscles are connected with the characteristic pose of the head, the manner of feeding, the great weight of the body and the strongly developed anterior part of the European bison. The specific gait and great activity of this animal is not without importance.

Department of Animal Anatomy

of the Central College of Agriculture, Warsaw, Grochowska 272.

\section{REFERENCES}

1. Duerst, J. U., 1926: Vergleichende Untersuchungsmethoden am Skelett bei Säugern. Urban \& Schwarzenberg: 125-530. Berlin-Vien.

2. Janicki, S., 1938: Badania nad szkieletem żubra (Bison bonasus L.). Prace Rolniczo-Leśne Pol. Akad. U., 27: 1-55. Kraków.

3. Juśko, J., 1953: Dimorfizm płciowy szkieletu żubra (Bison bonasus). Folia Morph., 1: 1—30. Warszawa. 
4. Koch, W., 1932: Uber Wachstums- und Altersveränderungen am Skelett des Wisents. Abh. Math. - naturw. Abt. Bayer. Akad. Wiss. Suppl. - Bd., 15 Abh.: 555-678. München.

5. Krysiak, K., 1951: Więzadło karkowe (Ligamentum nuchae) żubra Bison bonasus. Folia Morph., 2 (10): 271-283. Warszawa.

6. Poplewski, R., 1948: Anatomia ssaków. 2: 1-690. Czytelnik, Stockholm.

7. Świeżyński, K., 1961: Umięśnienie szkieletowe żubra (Bison bonasus L.). (typescript).

8. Ża biński, J., (ed.), 1947-1957: Pedigree Books of the European Bison. Int. Soc. for the Protection of the European Bison: 1-155. Warszawa.

\section{EXPLANATION OF PLATES}

Plate VI.

Phot. 1. Skulls: a) European bison, ơ, „Puk”, 17 years; b) Watussi cattle, $\sigma^{7}$, about 9 years.

Phot. 2. Skulls: a) European bison, + , „Pura”, 11 years; b) Watussi cattle, ㅇ, about 8 years old.

Plate VII.

Phot. 3. Thoracic vertebrae: a) European bison, ơ, „Puk”; b) Watussi cattle, ơ.

Phot. 4. Thoracic vertebrae: a) European bison, + , „Pura”; b) Watussi cattle, ..

Phot. 5. Highest thoracic vertebrae, from the left: Watussi female, about 8 years, European bison female, 11 years, Watussi, male, about 9 years, European bison, male, 17 years old.

\section{STRESZCZENIE}

Autorzy dysponowali 30 kośćcami żubra (18 samic i 12 samców) oraz 2 kośćcami bydła watussi (samiec i samica). Zwierzęta te były różnego wieku i pochodziły $\mathrm{z}$ polskich rezerwatów oraz ogrodu zoologicznego $\mathrm{w}$ Warszawie. Obserwacjom, a następnie pomiarom poddano czaszki i wyrostki kolczyste najwyższych kręgów piersiowych. Czaszki były także ważone. (Tabele 1-2, ryc. 1).

Przeprowadzone badania własne pozwoliły ustalić, że ogromna wysokość wyrostków kolczystych okolicy kłębu karkowego żubra nie jest uwarunkowana jakąś szczególnie dużą głową tego zwierzęcia. Bydło watussi posiada znacznie większą glowę, a jednak wyrostki kolczyste są o wiele niższe w porównaniu z żubrami (Fot. $1-5$, Tablice VI i VII).

Autorzy uważają, że potężne mięśnie okolicy kłębu ( $m$. spelenius,m. spinalis dorsi, $m$. spinalis cervicis, $m$. rhomboideus) decydują przede wszystkim o du- 
żym wzroście wyrostków kolczystych. Mięśnie te pozostają w związku $\mathrm{z}$ charakterystycznym ustawieniem glowy, sposobem pobierania pokarmu, dużym ciężarem ciała oraz silnie rozbudowaną częścią przednią żubra. Nie bez znaczenia jest tu także specyfika chodu oraz duża ruchliwość tego zwierzęcia. 
BIBLIOTEKA

Instytutu Biologii Ssaków

Polskiej Akademii Nauk

$\mathrm{NrCz} .40 .2$ 